\title{
Екстрена панкреатодуоденектомія при аденокарциномі голівки підшлункової залози, ускладненій гострою перфорацією виразки дванадцятипалої кишки
}

\author{
Національний інститут хірургії та трансплантології імені О.О.Шалімова НАМН Украӥни, Київ \\ DOI: $10.32471 /$ clinicaloncology.2663-466X.41-1.27734
} Резюме. Представлено випадок виконання екстреної панкреатодуоденектомії у хворого з аденокарциномою голівки під-
шлункової залози, ускладненою гострою перфорацією виразки дванадцятипалої кишки.

Ключові слова: панкреатодуоденектомія; рак підшлункової залози; перфоративна виразка дванадцятипалої кишки.

\begin{abstract}
ВСТУП
Про екстрену панкреатодуоденектомію як життєзберігаюче оперативне втручання в літературі повідомляється дуже рідко. Головним чином іiї проводять при ятрогенній перфорації дванадцятипалої кишки при виконанні ендоскопічної ретроградної панкреатохолангіографії чи ендобіліарних втручань, виразковій кровотечі у пацієнтів з резектабельними периампулярними пухлинами, аневризматичній кровотечі в кісту підшлункової залози та у випадках її складних травм [1]. Зважаючи на рідкість патології, не існує визначеного протоколу лікування перфорації, у тому числі ендоскопічної, за наявності злоякісної пухлини підшлункової залози чи периампулярної зони, і лікування в основному базується на досвіді та навичках лікуючих хірургів. У таких випадках можливе застосування паліативних способів, спрямованих на усунення ускладнення (зашивання перфорації, дренування жовчних проток та ін.), але показники смертності та ризики післяопераційних ускладнень $€$ надзвичайно високими. Крім того, відкладається виконання радикальної операції.
\end{abstract}

Екстрена панкреатодуоденектомія дозволяє одномоментно вирішити два завдання - лікування основної патології та ускладнення, однак супроводжується значно вищими показниками ускладнень (більше 80\%) та смертності (до 40\%), порівняно з плановою [2, 3]. За даними C. Тsаi та співавторів, за період 2001-2015 pр. лише у 31 (3,33\%) з 931 пацієнтів була виконана панкреатодуоденектомія за екстреними показаннями. Частота ускладнень становила $83,9 \%$, а летальність була суттєво вищою, ніж при плановій панкреатодуоденектомії $(19,4 \%$ проти $3,2 \%, p=0,015)$. При цьому затримка лікування понад 24 год після перфорації може призвести до подвоєння показників смертності [3].

Ми представляємо випадок успішного виконання екстреної панкреатодуоденектомії у хворого з аденокарциномою підшлункової залози, ускладненою гострою перфорацією виразки дванадцятипалої кишки.

\section{КЛІНІЧНИЙ ВИПАДОК}

Пацієнт О., 63 роки, звернувся в клініку 13.10.2020 р. зі скаргами на помірний біль в епігастральній ділянці, нудоту та періодичне блювання, відсутність апетиту, втрату маси тіла більше 20 кг за 2 міс хвороби. У зв'язку з явищами дуоденальної непрохідності в лікарні за місцем проживання 28.09.2020 p. ендоскопічним способом був встановлений назоінтестінальний зонд для ентерального харчування. Серед супутніх захворювань - вперше виявлений цукровий діабет II типу.

За даними комп'ютерної томографії, в голівці підшлункової залози визначається об'ємне утворення розмірами
$27 \times 38 \times 36$ мм, що перекриває просвіт дванадцятипалої кишки. Виявлено ознаки біліарної гіпертензії з розширенням загальної жовчної протоки до 21 мм та іїі конічним звуженням на рівні утворення. При езофагогастродуоденоскопії виявлено виразку на передній стінці ампули дванадцятипалої кишки 1,5 см в діаметрі.

Загальний аналіз крові: лейкоцити $-15,4 \cdot 10^{9} / л$, еритроцити $-5,59 \cdot 10^{12} /$ л, гемоглобін -166 г/л, тромбоцити $282,0 \cdot 10^{9}$. Біохімічний аналіз крові: білок загальний $-72,5$ г/л, глюкоза - 14,1 ммоль/л, білірубін загальний - 13,2 мкмоль/л, білірубін прямий - 4,0 мкмоль/л, аланінамінотрансфераза 20 Од/л, аспартатамінотрансфераза - 18 Од/л, креатинін 93,3 мкмоль/л, сечовина - 9,8 ммоль/л.

Клінічний діагноз: рак голівки підшлункової залози cT4NxM0. Декомпенсований стеноз дванадцятипалої кишки. Біліарна гіпертензія.

Пацієнта госпіталізовано о 10:35. Через 1 год після госпіталізації у хворого раптово виник гострий біль в епігастральній ділянці, блювання. Під час огляду визначаються симптоми гострої перфорації порожнистого органу. При рентгеноскопії органів черевної порожнини виявлено вільний газ під куполами діафрагми (рис. 1, 2).

У зв'язку з наявністю клінічної картини перфоративної виразки дванадцятипалої кишки прийнято рішення

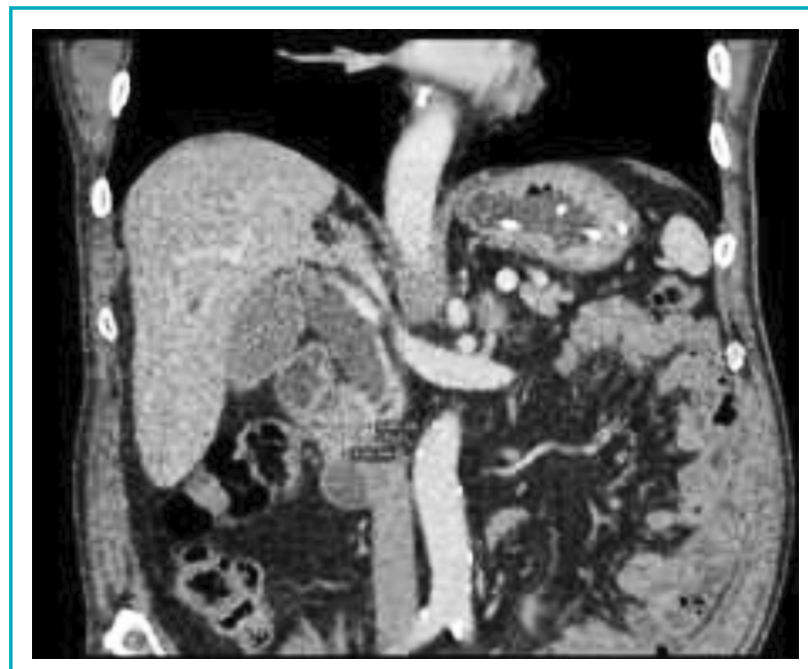

Рис. 1. Спіральна комп'ютерна томографія. Повна обтурація дванадцятипалої кишки на рівні Фатерового сосочка, розширення загальної жовчної протоки 


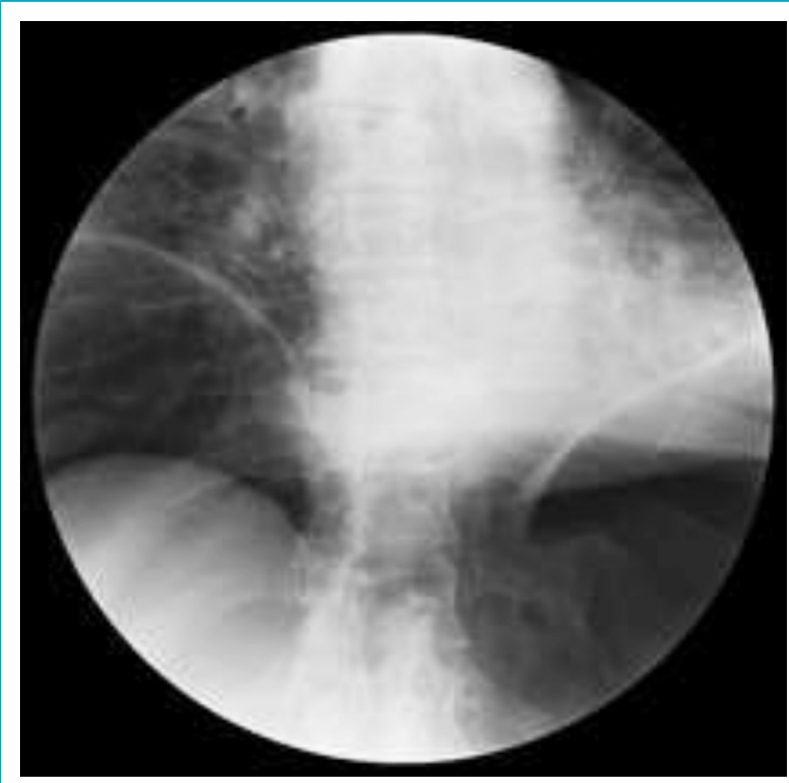

Рис. 2. Оглядова рентгенографія органів черевної порожнини. Вільний газ під куполами діафрагми

про необхідність екстреного хірургічного втручання. Операцію було розпочато після нетривалої підготовки о 15:35 (через 4 год) від моменту перфорації. Під комбінованою анестезією (загальна + епідуральна) виконано верхньо-серединну лапаротомію. У черевній порожнині було виявлено близько 300 мл мутної рідини. Петлі тонкого та товстого кишечнику не були роздуті, перистальтували. На передній стінці верхньо-горизонтального відділу дванадцятипалої кишки виявлено дві перфоративні виразки розмірами 2,0 та 1,5 см (рис. 3). Жовчний міхур значно збільшений в розмірах. Загальна жовчна протока - до 25 мм в діаметрі, стінки потовщені. У голівці підшлункової залози визначається новоутворення діаметром до 4,0 см, що обтурує просвіт дванадцятипалої кишки. Виконана санація черевної порожнини теплим фізіологічним розчином об'ємом 6 л та бетадином. Зважаючи на компенсований стан хворого та відсутність перитоніту, наявність поєднаної патології, прийнято рішення про виконання радикальної операції. Виконано пілорусрезектуючу панкреатодуоденектомію, холецистектомію, стандартну лімфаденектомію. Сформовані панкреатикоєюноанастомоз типу кінець-в-бік «duct-to-mucosa», гепатикоєюноанастомоз та попередуободовий гастроентероанастомоз з браунівським співустям. Встановлені дренажі до панкреатикоєюноанастомозу (2), в малу миску та правий піддіафрагмальний простір. Інтраопераційна крововтрата становила 300 мл, тривалість операції - 6 год 20 хв. Екстубацію здійснено на операційному столі.

Висновок гістологічного дослідження: протокова аденокарцинома голівки підшлункової залози, G-2, з інвазією в стінку холедоха, всієї товщі стінки дванадцятипалої кишки, ампули Фатерового сосочка та ознаками лімфоваскулярної та периневральної інвазії. По передній поверхні дванадцятипалої кишки виявлено 2 перфоративних виразкових дефекти на відстані 3,0 см від проксимального краю резекції. У лімфовузлах 13-ї групи (2/5) - метастази аденокарциноми.

Післяопераційний період проходив без ускладнень. Лікування проводилося згідно з програмою прискореного відновлення (Enhanced Recovery After Surgery - ERAS). На третю післяопераційну добу пацієнта в компенсованому стані було переведено в хірургічне відділення. Після рентгенологічного підтвердження наявності вільної евакуації із шлунку видалено назогастральний зонд, пацієнта переведено на пероральне харчування. Дренажі правого піддіафрагмального простору та малої миски були ви-

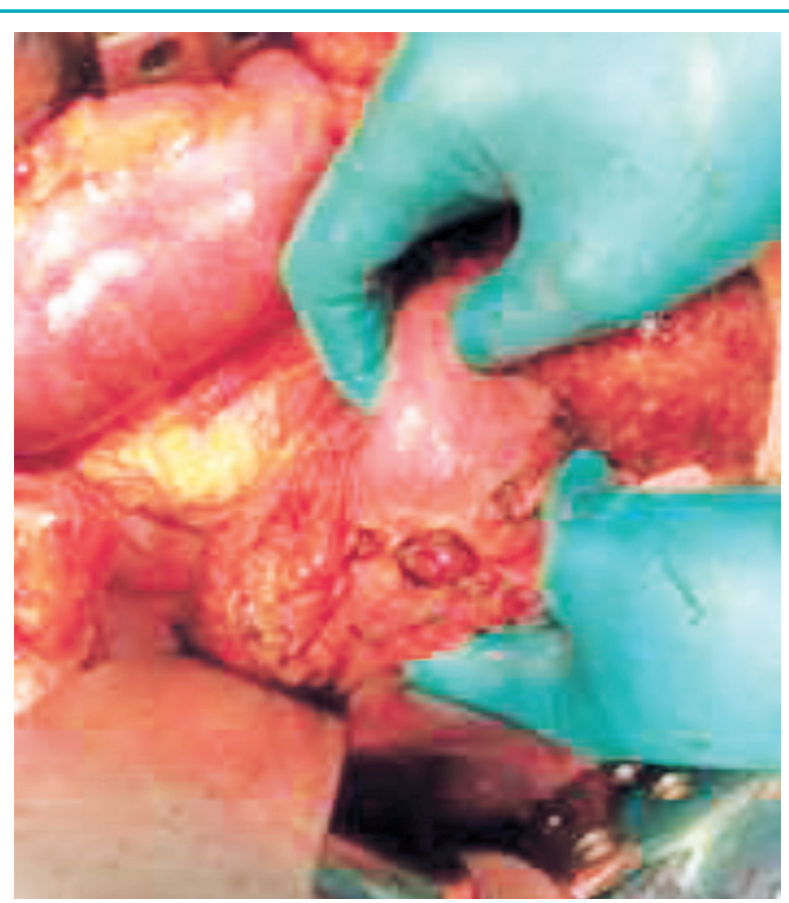

Рис. 3. Інтраопераційна фотографія. Дві перфоративні виразки ампули дванадцятипалої кишки

далені на шосту післяопераційну добу, зони панкреатикоєюноанастомозу - на восьму післяопераційну добу. Рана зажила первинним натягом. У задовільному стані пацієнта виписано 26.10.2020 р. через 13 діб після оперативного втручання.

Хворого було оглянуто через 3 міс. Скарг не має. Проходить курс поліхіміотерапії за схемою FOLFIRINOX.

\section{вИСновоК}

Наведене клінічне спостереження продемонструвало можливість успішного виконання панкреатодуоденектомії за екстреними показаннями за умови своєчасної діагностики. Екстрену панкреатодуоденектомію можна розглядати як операцію вибору при перфорації (у тому числі ятрогенній) дванадцятипалої кишки у пацієнтів з резектабельними периампулярними пухлинами за відсутності перитоніту чи сепсису.

\section{КОНФЛІКТ ॥НТЕРЕСІВ}

Автори заявляють про відсутність конфлікту інтересів.

\section{СПИСОК ВИКОРИСТАНОЇ ЛІТЕРАТУРИ}

1. Varshney. V.K., Nayar. R., Sreesanth. K.S. (2020). Emergency pancreatoduodenectomy for ampullary cancer post-iatrogenic duodenal perforation: no option but to strike. Cureus, 12(11), e11384. doi: 10.7759/cureus.11384.

2. Lissidini, G., Prete, F., Piccinni, G., Gurrado, A, Giungato, S., Prete, F., Testini, M. (2015). Emergency pancreaticoduodenectomy: When is it needed? A dual non-trauma centre experience and literature review. International Journal of Surgery, 21(1), 83-8. doi: 10.1016/j.ijsu.2015.04.096.

3. Tsai, C., Lai, B., Wang, S., Liao, Ch.-H., Liu, Y.-Y., Kang, Sh.-Ch., ... Yeh, T.-S. (2017). The impact of preoperative etiology on emergent pancreaticoduodenectomy for non-traumatic patients. World Journal of Emergency Surgery, 12, 21. doi: 10.1186/s13017-017-0133-6.

\section{EMERGENCY PANCREATODUODENECTOMY WITH ADENOCARCINOMA OF THE PANCREAS HEAD, COMPLICATED BY ACUTE PERFORATION OF ULCER OF THE DUODENUM}

A.V. Skums, A.A. Skums, D.Y. Zhytnik, R.O. Shelamova Shalimov's National institute of surgery and transplantation to National academy of medical sciences of Ukraine, Kyiv.

Resume. The case of performance of emergency pancreatoduodenectomy is presented in a patient with adenocarcinoma of the pancreas head, complicated by acute perforation of ulcer of the duodenum.

Keywords: pancreatoduodenectomy; pancreatic cancer; perforated ulcer of the duodenum. 


\section{Випадок із практики / A case from practice}

ЭКСТРЕННАЯ ПАНКРЕАТОДУОДЕНЭКТОМИЯ ПРИ АДЕНОКАРЦИНОМЕ ГОЛОВКИ ПОДЖЕЛУДОЧНОЙ ЖЕЛЕЗЫ, ОСЛОЖНЕННОЙ ОСТРОЙ ПЕРФОРАЦИЕЙ ЯЗВЫ ДВЕНАДЦАТИПЕРСТНОЙ КИШКИ

А.В. Скумс, А.А. Скумс, Д.Ю. Житник, Р.О. Шеламова Национальный институт хирургии и трансплантологии им. А.А. Шалимова НАМН Украины, Киев

Резюме. Представлен случай выполнения экстренной панкреатодуоденэктомии у больного с аденокарциномой головки поджелудочной железы, осложненной острой перфорацией язвы двенадцатиперстной кишки.
Ключевые слова: панкреатодуоденэктомия; рак поджелудочной железы; перфоративная язва двенадцатиперстной кишки.

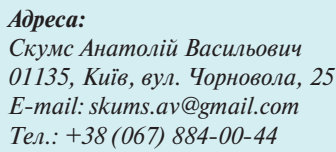

Скумс Анатолій Васильович

01135, Київ, вул. Чорновола, 25

E-mail: skums.av@gmail.com

Teл.: +38 (067) 884-00-44

Correspondence: Skums Anatolii Vasylovych 25 Chornovola street, Kyiv 01135, E-mail:skums.av@gmail.com Phone number: +38 (067) 884-00-44 